\title{
Study on the Spatial Characteristics of Landscape Services in Nature Reserve Based on Participatory Geographic Information System A Case Study of Jiuzhaigou Nature Reserve
}

\author{
Zhen-Hua BING ${ }^{1, a}$ and Ya-Wen WANG ${ }^{2, b}$ \\ ${ }^{1}$ Shanghai Business School, No.123 Fengpu Road, Fengxian District, Shanghai, Ching \\ ${ }^{2}$ Hult International Business School, 1 Education Street Cambridge, Massachusetts, USA \\ axiaobing0707@126.com, ${ }^{b}$ 512339767@qq.com
}

\begin{abstract}
Keywords: Landscape Services, Spatial Characteristics, Participatory Geographic Information System, Environment Management
\end{abstract}

\begin{abstract}
This paper comprehensively adopted the Geographic Information System (GIS) and Participatory Geographical Information System (PGIS) technologies to construct the Jiuzhaigou Nature Reserve's landscape services index system and analyzed the landscape services spatial characteristics. The results show that the perception of landscape services of the Jiuzhaigou Nature Reserve varies greatly among the respondents. The number of landscape services points for rare animals habitat, forest recreation, and returning farmland exceed half of the total number, accounting for $53.78 \%$. At the same time, the spatial distribution of landscape services points has a strong agglomeration, with the most concentrated distribution around residential areas. It can be seen that residents' perception of landscape services mainly comes from the vicinity of residential areas. With the increase in distance from residential areas, the density of landscape services points gradually decreases. The areas with the greatest intensity of landscape services are concentrated around Zharugou, Shuzhenggou and Nuorilang Tourist Service Center. The landscape services categories are unevenly distributed in different regions, and the landscape services in Shuzhenggou and Zharugou are most densely distributed.
\end{abstract}

\section{Introduction}

Ecosystem services are already a comprehensive and mature concept. Most of them are assessed through economic and monetary values[1-5]. However, this method only assesses the content of land and resources that can be monetized and ignores social culture[6-9]. At the same time, the problem of spatial heterogeneity has not been answered in the existing assessment methods.

The provision of landscape services depends not only on the ability of the landscape to provide services, but also on the demand of the community for its services. Termoschuizen and Opdam proposed "Landscape Services", which considers landscape services as an additional ecological, social and economic value brought about by human activities that promote landscape change and multi-functionality [10]. According to Willemen et al. (2005), "Landscape Services" is the mobile service provided by landscapes from the ecosystem to human society[11]. Ralf-Uwe Syrbe and Ulrich Walz also proposed that landscape services can be a new auxiliary item for assessing ecosystem services from spatial indicators, and highlights the perfection of ecological service evaluation by landscape services on spatial indicators [12].

Therefore, building a landscape services index system based on the relationship between supply and demand of landscape ecosystems, and adopting public participation in geographic information system technology to digitize landscape service indicators will be one of the ways to evaluate landscape services. 


\section{Research Methods and Statistics}

\section{Landscape Service Index Classification}

The landscape service indicators need to emphasize all the tangible services and intangible services provided by the landscape ecosystem. As Jiuzhaigou Nature Reserve is a living area for local communities, it is also a famous tourist destination. Therefore, the surveyed groups assessed by the landscape service include residents, tourists and staff of the Jiuzhaigou District Administration.

Based on the research results of Fagerholm [13], this paper combines the remote sensing image data of Jiuzhaigou in 2012 and the landscape classification related data for index selection, and adopts the method of research meeting to revise the unserviceability index and missing indicators of landscape services. According to statistics, there are 18 landscape service indicators, which are five categories of supply services, recreation services, support services, cultural services, and ecological services( Table 1).

\section{Public Participation Mapping and Data Collection}

The data of landscape services was statistically analyzed through a combination of interviews by visitors, residents and staff, and GPS positioning. For each landscape service indicator, when more than three respondents considered that the landscape with the same geographic coordinates (error within 300 meters) has a certain service or function, this indicator was included in the statistics.

At the same time, in order to study the spatial differentiation of the density and intensity of different landscape services, each survey question has a scale and intensity of 1-5 points. Only if the average of the attribute options is greater than 1.5 (not equal to 1.5), it was included in the statistics. 
Table1 Landscape Service Index Classification \& Data Collection

\begin{tabular}{|c|c|c|c|c|c|}
\hline \multirow[t]{2}{*}{ Landscape service indicator } & \multirow[t]{2}{*}{ Category } & \multirow{2}{*}{$\begin{array}{l}\text { Remote } \\
\text { sensing } \\
\text { image data }\end{array}$} & \multirow{2}{*}{$\begin{array}{l}\text { Scenic } \\
\text { real-time } \\
\text { data }\end{array}$} & \multicolumn{2}{|c|}{ Field collection } \\
\hline & & & & $\begin{array}{l}\text { Observatio } \\
\mathrm{n}\end{array}$ & Interview research \\
\hline Returning farmland & ecological service & $x$ & & $x$ & $x$ \\
\hline $\begin{array}{l}\text { Folk facilities and residential } \\
\text { buildings }\end{array}$ & support service & $x$ & & $x$ & \\
\hline Poultry & supply service & & $x$ & & $x$ \\
\hline Medical materials & supply service & & $x$ & & $x$ \\
\hline Crop & supply service & & $x$ & & $x$ \\
\hline Bird habitat & support service & & $x$ & $x$ & $x$ \\
\hline Other rare animals habitat & support service & & $x$ & $x$ & $x$ \\
\hline Forest recreation & recreation service & & & $x$ & $x$ \\
\hline Ornamental plants & recreation service & & $x$ & $x$ & $x$ \\
\hline Geological beauty & recreation service & & $x$ & $x$ & $x$ \\
\hline Ornamental water & recreation service & & $x$ & $x$ & $x$ \\
\hline Camping tourism & recreation service & & & $x$ & $x$ \\
\hline Spiritual belief & cultural service & & & & $x$ \\
\hline Sacrifice activities & cultural service & & & & $x$ \\
\hline Folk and festive events & cultural service & & & & $x$ \\
\hline Environmental interpretation & ecological service & & $x$ & $x$ & $x$ \\
\hline Environmental monitoring & ecological service & & & $x$ & $x$ \\
\hline Sewage treatment & ecological service & & $x$ & $x$ & \\
\hline
\end{tabular}

\section{Landscape Service Digitalization}

This study uses Arcgis10.0 software for digitization. First, it overlays points data and geolocation into landscape service points distribution maps.Secondly, the landscape service indicators summary map vector is converted to a grid. An area data attribute association tool is used to form the landscape service map with the most adjacent landscape service points as a polygon. 

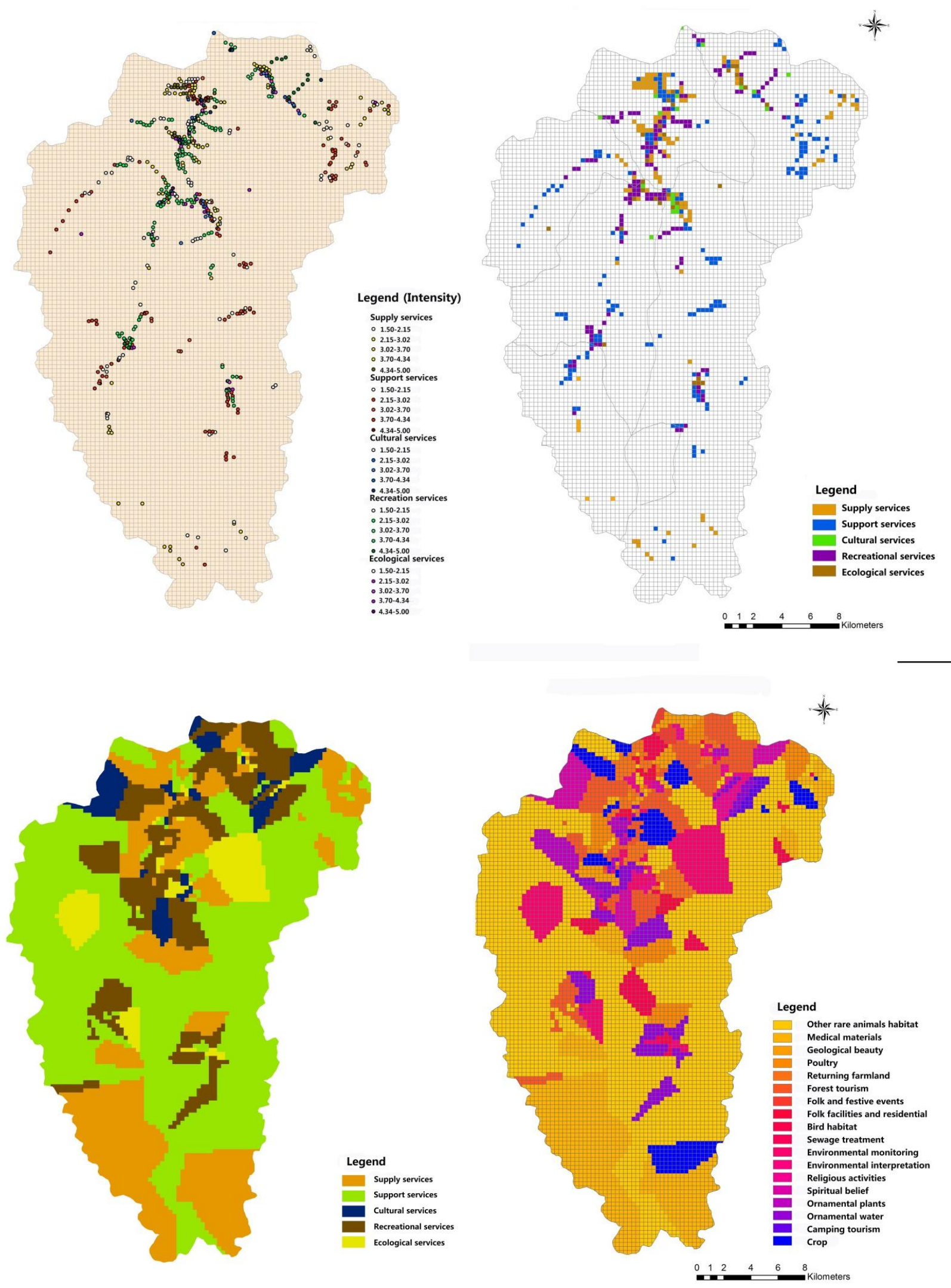

Fig. 1 Landscape Service Points - Grid -Landscape Service Classification - Landscape Service Indicators 


\section{Results}

\section{Data Analysis}

Among the 649 landscape service metrics obtained from the statistics, the most highly perceived objects were rare animals habitat, and residents and staff had very high awareness of rare animals habitat. A total of 188 landscape service sites were surveyed, accounting for $28.97 \%$ of the total number of landscape service points. Followed by forest recreation services, this perception of landscape services mainly comes from tourists and residents. A total of 89 landscape service sites were surveyed, accounting for $13.71 \%$ of the total; 72 landscape service sites of the returning farmland accounted for $11.09 \%$ of the total. The number of landscape service points for rare animals habitat, forest recreation, and farmland reclamation exceeded half of the total number, accounting for $53.78 \%$. It can be seen that the surveyed objects have higher awareness and concentration of the above types of landscape services.

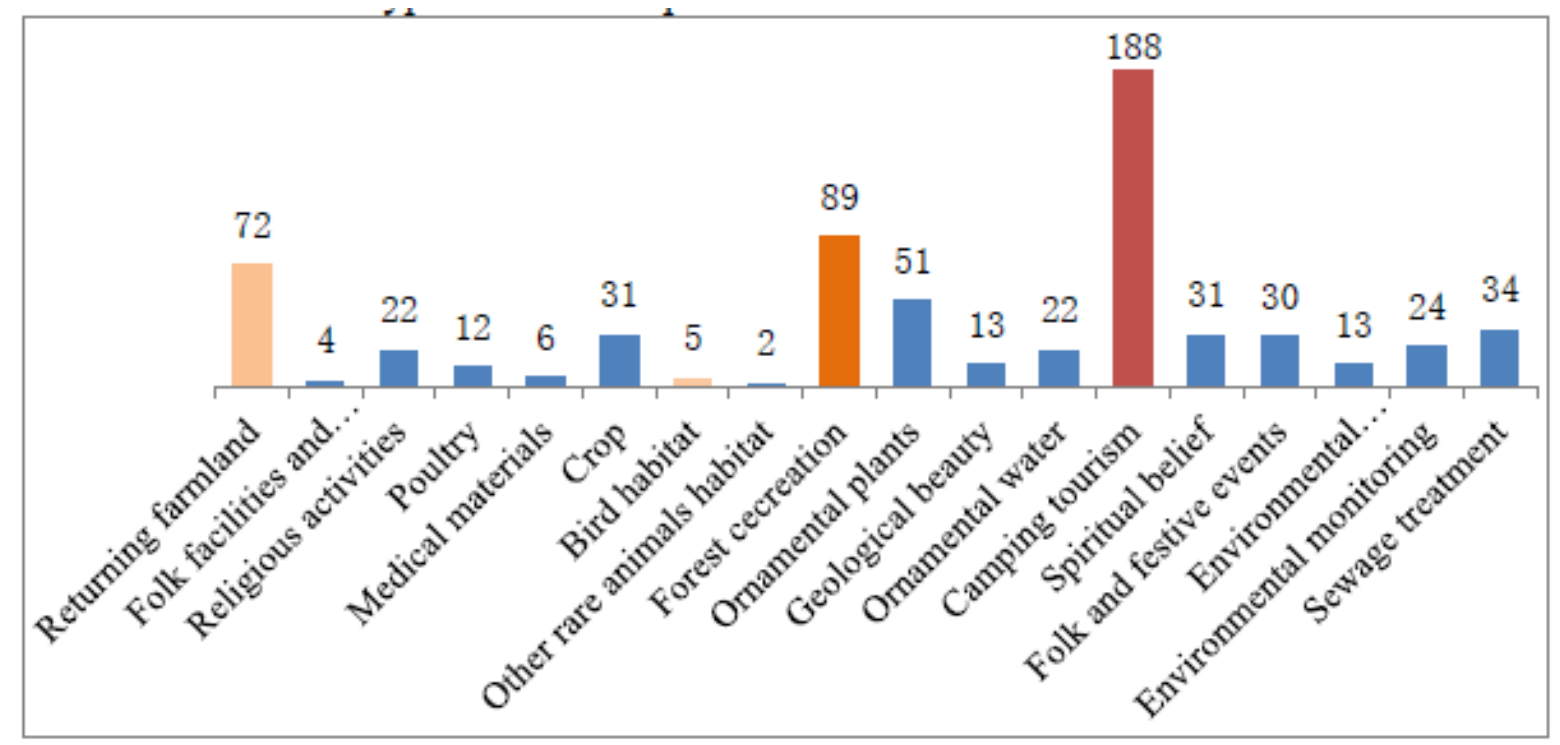

Fig. 2 Distribution of Landscape Service Points

\section{Density and Intensity of Landscape Service Points}

In this paper, spatial density and intensity of landscape service points are analyzed with $300 \mathrm{~m} * 300 \mathrm{~m}$ cells and $800 \mathrm{~m} * 800 \mathrm{~m}$ cells respectively.

The largest density in the $300 \mathrm{~m}$ unit is 6 landscape service points, and the highest density in the $800 \mathrm{~m}$ unit is 13 landscape service points. The areas with higher density of landscape services are concentrated in the surrounding areas of Shuzheng Village, Heye Village, Zharu Village and Chazhe Village. It can be seen that the perception of landscape services of the surveyed objects, especially residents, mainly comes from the vicinity of the residential area. With the increase of the distance from the residential area, the density of landscape service points gradually decreases. 

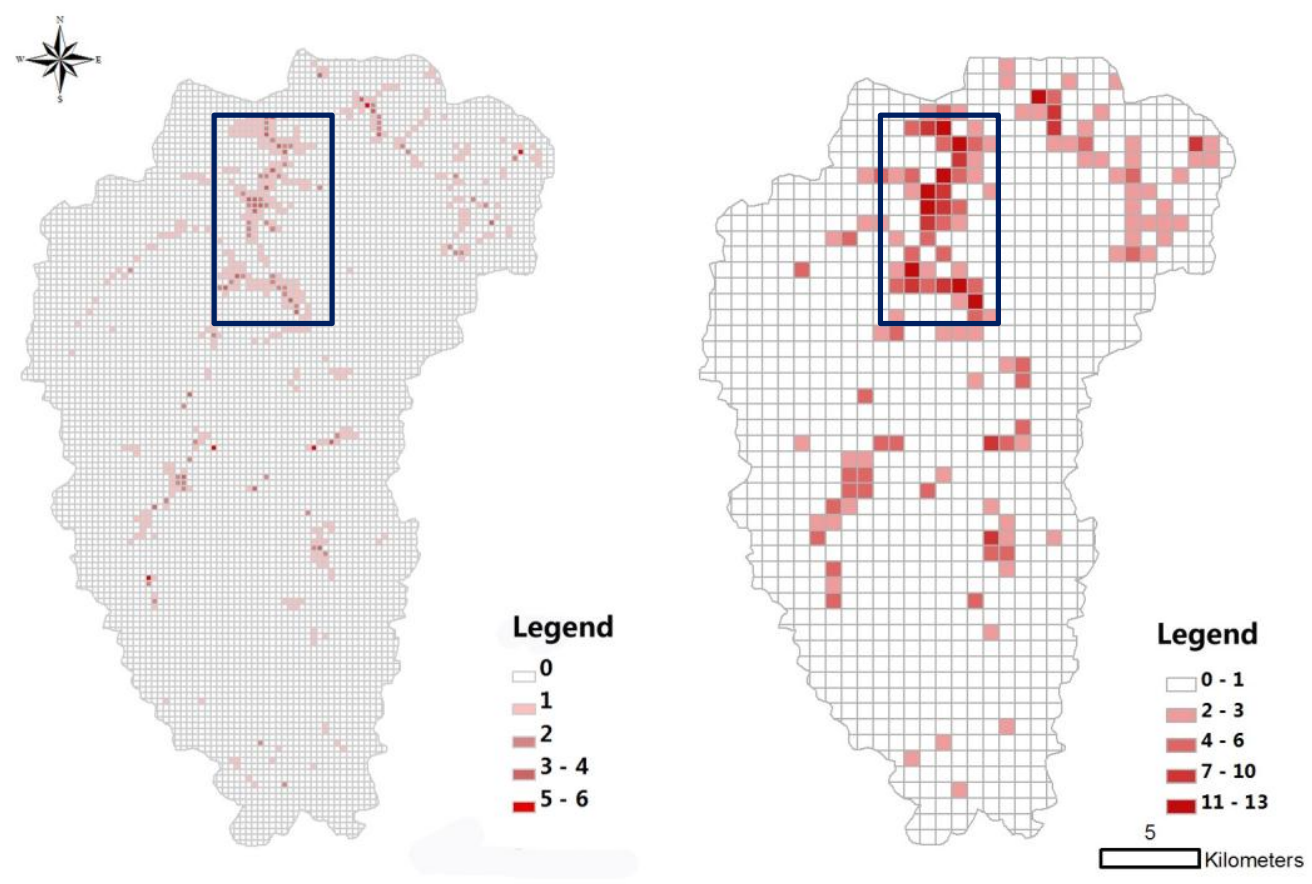

Fig. 3 300m and 800m cell landscape service index density distribution
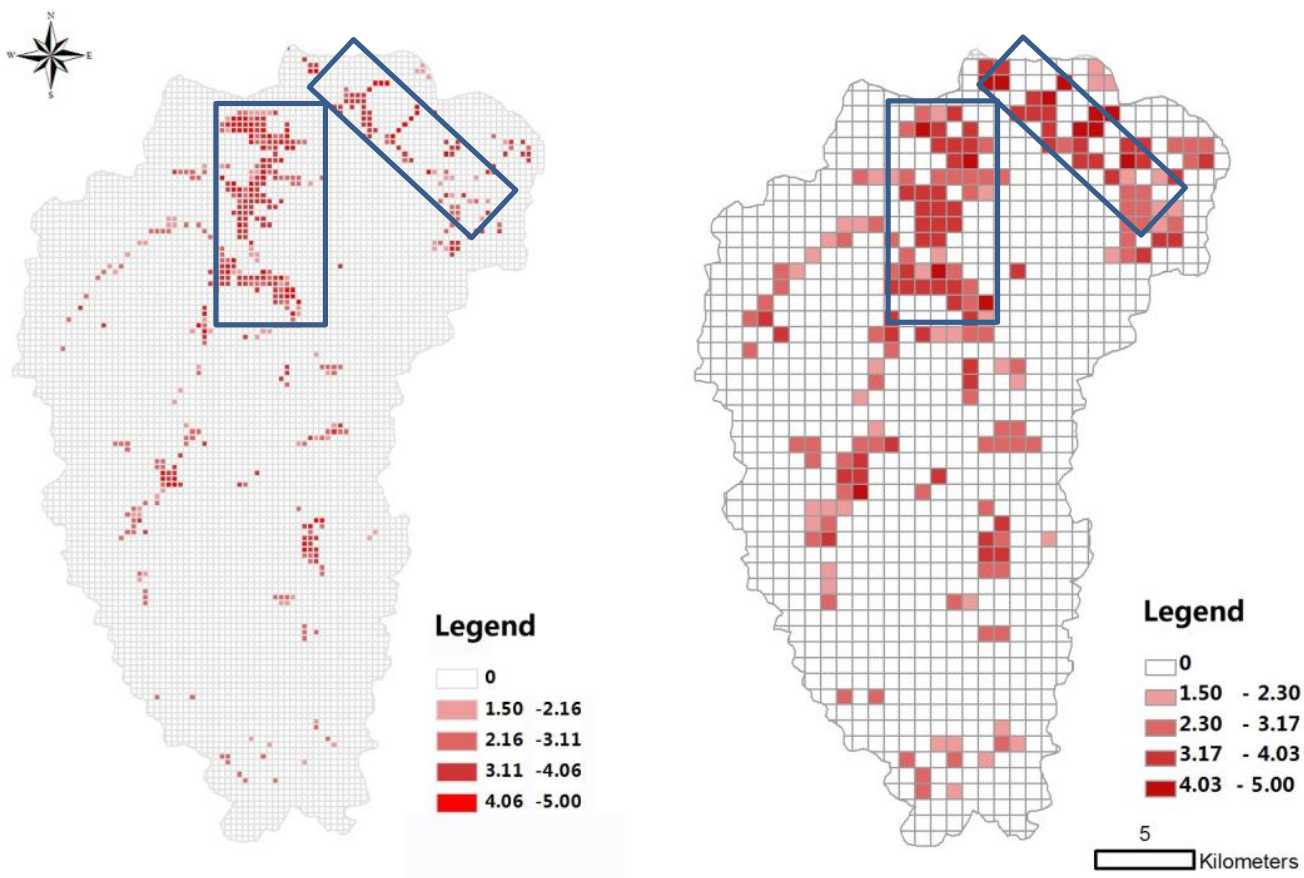

Fig. 4 300m and 800m cell landscape service index intensity distribution

The areas with the greatest intensity of landscape services are concentrated in Zharugou, Shuzhenggou and Nuorilang tourist service centers. Although Zharugou is not open to the general public, residents and ecotourists have a higher overall assessment of their landscape services. The highest scores were for landscape services such as forest recreation, camping tourism and spiritual beliefs.

The conclusion shows that public demand for landscape services has a certain degree of spatial agglomeration in the survey. The regular results have a good indication of the spatial distribution characteristics of landscape services. 


\section{Spatial Distribution Characteristics of Landscape Service Area}

This study divides landscape services into support services, supply services, cultural services, ecological services, and recreation services. Among them, the largest number of support service categories was 90 service points, followed by recreational services and provision services, with 63 and 58, respectively. The number of landscape service points for cultural services was the least. Different landscape service categories are unevenly distributed within nature reserves. Taking the number of plaques as an example, landscape services are mainly concentrated in Shuzhenggou, followed by Zharugou.

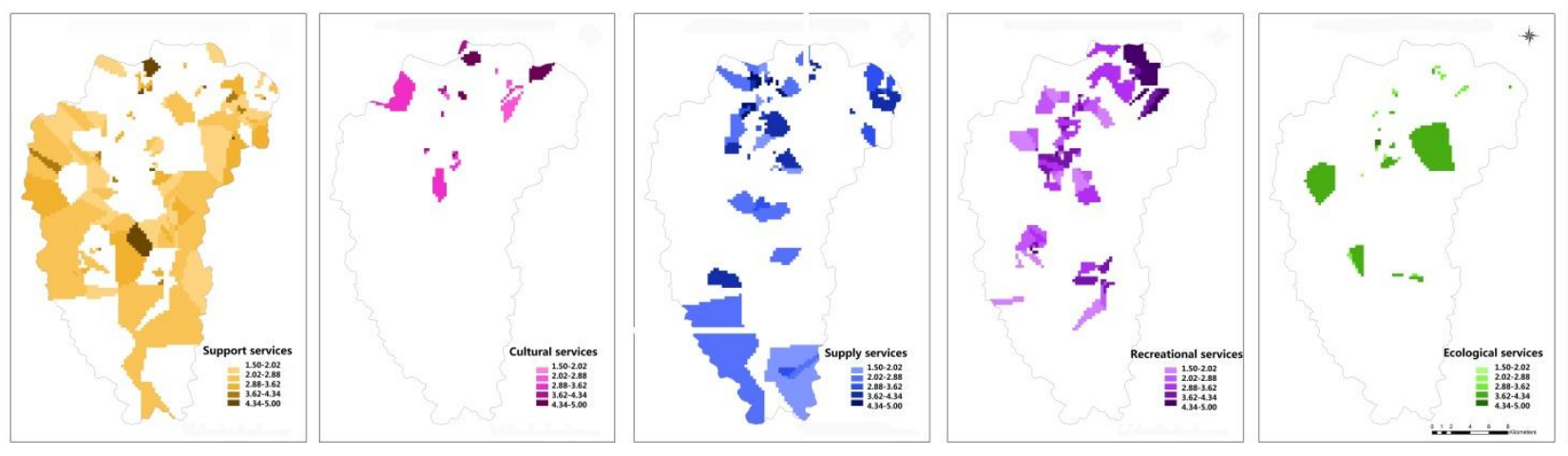

Fig. 5 Jiuzhaigou Nature Reserve Landscape service partition (Intensity)

\section{Conclusions and Discussions}

Based on relevant overseas empirical studies and the resource classification of Jiuzhaigou Nature Reserve, the indicator system for landscape services was divided into five categories and 19 indicators such as rare animals. The results of the study showed that the perception of the landscape services of the Jiuzhaigou Nature Reserve varies greatly among the respondents. The highest density of landscape service points was other rare animals habitat, forest recreation, and returning farmland. The number of three landscape service points accounted for more than half of the total.

At the same time, the spatial distribution of landscape service points has strong agglomeration, with the most concentrated distribution around residential areas. The area with a higher density of landscape services is concentrated in the surrounding areas of Shuzheng Village, Heye Village, Zharu Village and Chazha Village, and other tourist attractions are also geographical units with dense landscape services. The areas with the greatest intensity of landscape services are concentrated around Zharugou, Shuzhenggou and Nuorilang Tourist Service Center.

It can be seen that the perception of residents' landscape services mainly comes from the vicinity of residential areas. With the increase in distance from residential areas, the density of landscape service points gradually decreases.

In the management of nature reserves in China, the core area, buffer zone and experimental area have always been the main basis for district management. This article attempts to spatially correlate landscape architecture with landscape services. From comparative analysis of different ditch and circle in Jiuzhaigou Nature Reserve, we can see that the spatial distribution of landscape structure and service is uneven, and the function and service of nature reserve are not completely spread from the center of the experimental zone to the surrounding. Therefore, the spatial distribution of landscape services and value can provide a new perspective for the protection and management of nature reserves, and promote the protection and sustainable development of nature reserves.

\section{Acknowledgement}

This research was financially supported by the National Natural Science Foundation of China "Landscape Services Spatial Heterogeneity Assessment and Supply Forecasting Simulation_—A 
Case Study of Chongming Dongtan Wetland Bird Nature Reserve in Shanghai” (41701633) and the Qi Mingxing Project of Shanghai Business School.

\section{References}

[1] G.D. Xie, CH.X. Lu, Y. Xiao, The economic evaluation of grassland ecosystem services in Qinghai-Tibet plateau, J. Journal of Mountain Science, 21(2003), 50-55.

[2] CH.X. Lu, G.D. Xie, Y. Xiao, et al. Ecosystem diversity and economic valuation of QinghaiTibet Plateau, J.Acta Ecologica Sinica, 24(2001), 2749-2755.

[3] G.C. Daily, Nature's Service: Societal Dependence on Natural Ecosystem, Island Press, Washington, D C: 1997.

[4] R.S. De Groot, M.A. Wilson, R.M.J. Boumans, A typology for the classification, description and valuation of ecosystem functions, goods and services, J. Ecological Economics, 41(2002), 393-408.

[5] G.M. Lange, N. Jiddawi, Economic value of marine ecosystem services in Zanzibar: implications for marine conservation and sustainable development, J. Ocean \& Coastal Management, 52(2009), 521-532.

[6] F. Luz, Participatory landscape ecology: a basis for acceptance and implementation, J. Landscape Ecology, 50(2000),157-166.

[7] Ü. Mander, H.Wiggering, K. Helming, et al. Multifunctional Land Use: Meeting Future Demands for Landscape Goods and Services, J. Springer, Heidelberg, Berlin, 2007,153-166.

[8] P. Raquez, E.F. Lambin, Conditions for a sustainable land use: case study evidence, J. Land Use Science, 1(2006), 109-125.

[9] E.HZube, Perceived land use patterns and values, J. Landscape Ecology. 1(1987),37-45.

[10] J.Termorshuizen, P.Opdam, Landscape services as a bridge between landscape ecology and sustainable development, J. Landscape Ecology. 24(2009), 1037-1052.

[11] L. Willemen, A.Veldkamp, P.H.Verburg, et al. A multi-scale modeling approach for analyzing landscape service dynamics, J.Journal of Environmental Management, 100(2012), 86-95.

[12] R.U. Syrbe, U.Walz, Spatial indicators for the assessment of ecosystem services: Providing, benefiting and connecting areas and landscape metrics, J. Ecological Indicators, 12(2012), 80-88.

[13] N. Fagerholm, N. Kahko, F. Ndumbaro,et al. Community stakeholders' knowledge in landscape assessments-mapping indicators for landscape services, J. Ecological Indicators.18(2012),421-433. 